\title{
When Practitioners (Don't) Call and Scholars Remain Mute
}

\section{Christoph Konrath}

Austrian Parliament, Parlamentsdirektion

christoph.konrath@parlament.gv.at

\section{Perceptions}

What is the use of political science? - I do hear this question quite often and it is accompanied by statements like "Political scientists are just stating the obvious," or "They have no idea of real politics or how things work in public administration". There is laughter when political scientists present statistical analysis and the audience concludes that the answer to the problem is to be found somewhere around '+0.9'. There is also an understanding that politics is a craft or a skill that needs to be mastered and strategically reviewed but not necessarily analysed by a set of elaborate methods and theories.

The situation in Austria is different when the same crowd listens to or consults academics with a background in law. They are expected to tell them what can be done (not necessarily what 'ought' be done) under the given circumstances. And it is assumed that at least some of them know how politics work. Finally, it is accepted that legal scholars can offer policy-analysis and strategic advise even though they may just utter general assumptions without a sound theoretical or empirical basis.

I consider myself as a kind of go-between between various disciplines and fields of practice. I studied law and politics and work in public administration though with a strong focus on research. The ominous 'audiences' I have referred to in the first paragraph are people I meet in my field of work. Some of them studied political science and say that the degree was rather easy to obtain and fitted well with their political activities. Further on, many programs allowed them to circumvent the tricky methodological parts quite easily. I get similar remarks from students of political science. They want to talk politics and complain when I demand empirical research or theoretical reflection.

And while political science is still a convenient option for many who want to do "something with politics" it is generally agreed upon that if you want to succeed in the political realm you either don't bother too much with academia or study something 'real' like law or even better business administration.

Political scientists working at universities or other (academic) research institutions don't seem to like such discussions and many of them seem to avoid exposure to such an audience. Theirs is the world of academic distinction and international recognition. And when they ask themselves about the wider relevance of the discipline they may not be able to transcend their professional context - which is, paradoxically, also true of this special issue that will most probably not reach out to other audiences in Austria simply because the contributions (including this one) are written in English.

\section{Challenges}

We find ourselves amidst challenges to liberal democracy and its social and epistemic foundations. In Austria, these challenges add to transformations of the political and administrative realm that have started in the late I 980 . They can be described by the gradual decline of law and legal expertise in public administration and politics and the diminishing role of the social partner organisations as primary institutions of policy analysis and policy formulation.

For long, the social architecture of Austria has been characterised by the dominant role of the state (cf. Hanisch 1994) and a distinct kind of legalism (cf. Wiederin 2007) that invested the legal profession with a leading role in politics and administration. Consequently, political questions could be framed in a legal way and academic legal experts were (and still are) at hand to explain what to do now. And although academics with a legal training dominated the formative years of political science in Austria they did never really challenge this situation (Ehs/König 20I2). 
Interestingly, this distinctive Austrian legalism has always been quite detached from legal academic discourse as it is known elsewhere. It has a strong focus on dogmatic thinking derived from meticulously observed court rulings and administrative practice. It does not pay much attention to methodological and theoretical questions on the one hand (Wiederin 2007; Somek 2007) and to the political context on the other. It is characterised by a strong notion of self-evidence shared in the legal community which makes it hard for outsiders to understand even basic institutional settings and which is one of the reasons why Austria has such underdeveloped administrative and public policy studies, today (cf. Biegelbauer/ Konrath/Speer 20I4).

A somehow similar detachment from the academic discourse can be observed in the field of policy analysis. It has for long been dominated by social partner organisations like the Arbeiterkammer (Chamber of Labour), the Wirtschaftskammer (Chamber of Commerce), the Industriellenvereinigung (the Federation of Austrian Industries) and affiliated organisations. Further on, there are the (academic) economic research institutions. Finally, there are the so-called academies of the political parties funded by public money (cf. Bandelow/Biegelbauer/Sager 20I3). Again, we can discern a focus on questions and solutions coming from practical insights and we can (or could) find a strong role of legally trained personnel and a significant increase of economists and business analysts.

Although legalism retains a strong role in parts of the public administration the influence of managerial approaches has been on the increase for years. This is most evident on the shift to performance-based budgeting in the mid-200os (cf. Steger 20IO) and public governance (with a strong leaning on management techniques). Both approaches have been propagated by senior public officials in order to develop a "self-confident administration" and both fit well with political aims and demands (cf. Biegelbauer/Konrath/Speer 2014). At the same time, social partner organisations have seen growing public criticism (Praprotnik/Jenny/Müller 20I5) and economic research institutions struggle for funding. In addition, the political party academies have (with the exception of the liberal party academy neosLab and the Green "Bildungswerkstatt") shifted their focus to rhetoric and presentation techniques.

Both developments happen in a time in which democratic institutions are constantly loosing public trust and in which it is unclear where our liberal democratic systems are heading to. There are, of course, experts at hand to explain what is happening. Interestingly, these are - in addition to the already mentioned legal experts - predominately former party managers-turnedconsultants, political scientists owning or employed by public-opinion research companies or historians. What they mostly offer are opinions on polls and current affairs, strategic appraisals and descriptions of (historical) developments. What they do not offer is wider insight and political analysis that could substantially contribute to the debates at hand.

This is a phenomenon that makes Austria quite exceptional among many European countries. It affects the wider context of what and how we talk about politics in public and how we think of civic education in schools or the public service (including military service etc.).

(Sidenote: As you can see from my references the transformation of the legal and administrative system has received at least some attention in academia. But there's almost nothing on the role of political party academies, public experts and civic education in political science.)

\section{Questions}

One might think that this should be "the hour" of political science in Austria. When the disciplines and groups that are here to explain politics struggle and the political (and not just the legal or administrative) system faces severe challenges, then those should enter the stage who are able to analyse and explain the situation.

From what I perceive in my professional environment the demand for such expertise is in fact growing. But this does not necessarily lead to the consultation of political scientists. I have mentioned some (possible) reasons already. We might also want to discuss the question of what are the grounds to consult certain experts. Research from other countries (cf. Blum/Schubert 20I3) points to their academic and public standing, political affiliations but also to innovative approaches that dare to bring hitherto unknown but outstanding academics and politicians together (Zaal 2014). Such research is lacking in Austria (another desideratum, I guess). Still, the focus here is on the demand-side. When we want to discuss the wider relevance of political science in Austria we should also look on the supply-side.

I work in the Legal, Legislative and Research Service of the Austrian Parliament. This unit has, as its name indicates, a strong focus on legal counselling. It also comprises the library and information services which are dedicated to a librarian approach meaning they supply information but do not provide for material analysis. In the context of the changes in the Austrian fiscal framework and the re-orientation of the federal administration a further expert centre, the so-called Budget Office, was established in 2012 that offers expert advice to Members in fiscal and economic matters. But there is an increasing number of questions that does not really fit with the approaches of those units. Some of them regard technological developments and shall be addressed in a recently established co-operation with two research 
institutions (Parlamentskorrespondenz 2017). Still, a lot of questions remain. They concern political processes and policy matters. Such questions are actually the standard questions that parliamentary research services receive from their clients. They are not so much interested in how something is regulated (which would be the standard legal approach) but more in how something is done and managed elsewhere and what effects it has (Konrath 20I4).

Typical questions are, for example:

- How could electoral laws and financial incentives contribute to stronger women representation in Austria?

- What can be done to make citizen participation in parliament more effective in Austria?

- How can the dynamics of fiscal federalism be contained and improved in Austria?

These are fairly standard questions for political science, I would suppose. The first addresses the design and effects of electoral rules and central problems of the theory and practice of representation. The second relates not only to challenges of most parliamentary democracies but also to two important branches of political science namely democratic innovations and parliamentary research. And the third is a standard question for any federal system and a widely discussed topic in comparative political science. There's quite a lot on them in the international literature and a number of case studies can be found (cf. Fortin-Rittberger/Rittberger 2013; LestonBandeira 20I2; Benz 20I2). But there's almost nothing on Austria.

I'm aware of the fact that the number of political scientists who are actively pursuing academic research in Austria is comparatively low and that they cannot cover all possible topics. Also, I know about the demands of academic recognition and the means to succeed in international journals. But still I struggle to explain why political scientists in Austria don't offer much on these exemplary questions. Even more, I find it much harder to explain this situation to colleagues or clients.

Yes, there may be an overview or the other. But this will often be on such a broad level that it really doesn't offer someone 'from within' any new insights. And many overviews just rest on deductions from general theories and general assumptions without much empirical basis from Austria. There is, of course, high quality research on elections in Austria, but there's not too much on electoral rules (cf. Eder/Jenny/Müller 20I5) and even less on substantial matters of representation. There is internationally renowned research on women representation (cf. Fortin-Rittberger/Rittberger 20I3). There are only a few spotlights on citizen participation (cf. Rosenberger/Stadlmaier 2015; Biegelbauer/Kapeller 2017), while fiscal politics and federalism are more or less left to a handful of economists.

I'm well aware of the countless hours of framing questions and coding that stand behind this kind of research. However, in the end it leads more often than not to extremely high levels of abstraction, narrow methodological debates and a way to present highly aggregated data only accessible to specialists. At the same time, this level of abstraction provokes the - quite justified - question from those in the field that a lot of rules, actors or practices were not considered or overlooked and that this lack may seriously influence any judgements made on basis of such a text.

\section{What now?}

I have made different experiences, too. In my professional and in my voluntary activities I regularly invite political scientists for presentations and discussions. When I teach junior civil servants or engage in civic education I try to include approaches from political science. Every time it is important to take great care in how research and methodology are presented and explained and how one is willing to adapt to the audience. Suddenly, it is not "just stating the obvious" or "making simple things look complicated" but a surprise about how political science can explain developments and put them in a theoretical and historical context. And in the end, the invited speakers said that they had also learned a lot from their audience. These are two central points: Communicating research and willingness to engage with a wider audience or the public.

Let me give an example: Among academics, journalists and public servants it is common to ridicule 'one pagers' or 'two pagers' prepared for senior staff and politicians. The saying goes that today the addresses of those briefs are just too dumb to process more information. So far, however, no one could answer my question whether politicians had read long briefings and studies 15 or 20 years ago. Of course, names of ardent readers will be dropped. But the chances are high that they were a minority back then as well.

There is an intense debate among parliamentary libraries and research services in Europe on how to serve their clients - politicians and the public - best. It is not so much about conducting one's own (original) research but much more about how to communicate research and engage academics and politicians. Improving the former still ranks on top of the wish list of members who demand more service and journalists and academics who complain about the poor performance of parliaments. Conducting original research needs - most importantly - time (which is lacking more often than not). It will most often be given only for highly contested legal or fis- 
cal topics. It is therefore much more important to look on what's already available, how it can be found and presented. Then, things like the notorious "two pager" will not impart very simplified and condensed information but become a means of communication that can channel and foster interest in certain topics. Blogs or blog-like documents and infographics are becoming increasingly important not because they are trendy but they allow for a language and presentation that is accessible for the target-audience. In this regard, academic blogs become an invaluable tool, too, as they make academic research available without the constraints of academic journals (but still with sound reference to them). The same applies for personal exchange between politicians and academics in a way that allows the former to ask questions without fearing to get exposed.

These are, of course, rather general observations and recommendations. They do not apply to political science alone. But, so I think, political science can learn a lot from it if it wants to have wider social relevance.

Given the challenges liberal democracies face today and the transformations Austria faces in particular there is a need to explain and review the workings of state and politics that can neither be fulfilled by law, journalism or managerialism. Each of them looks only at particular elements or follows specific interests while political science has the instruments to connect normative theories and practical insights. But in order to achieve this it must be open in two ways: to disciplines that share the object of interest - law, economics, history or sociology, and to 'practice' in political institutions, the administration, the courts and the public.

Both are, in my opinion, lacking. As long as there is only marginal interest in exchange with other disciplines or the, admittedly, tough work on arcane institutions political science will forfeit its chances and deny the role it could (and in my opinion should) have. As long as curricula are either designed for those who want to 'study something' or those who aim for international academic excellence, political science will either be a collection of anecdotes and opinions or a strange pursuit to get recognition of a small expert community by formulating ever more extraordinary hypotheses.

\section{References}

Benz, Arthur/Felix Knüpling (eds.) (2012), Changing Federal Constitutions. Lessons from International Comparison, Leverkusen: Budrich.

Bandelow, Niels C./Peter Biegelbauer/Fritz Sager (2013), Policy analysis in the German-speaking countries: common traditions, different cultures, in Germany, Austria and Switzerland, in: Blum, Sonja/Klaus
Schubert (eds.), Policy analysis in Germany, Bristol: Policy Press, 75-89.

Biegelbauer, Peter/Sandro Kapeller (2017), Mitentscheiden oder Mitgestalten: Direkte Demokratie versus Deliberation in lokalen Entscheidungsfindungsprozessen, in: SWS-Rundschau, Vol. 57(I), 32-55.

Biegelbauer, Peter/Christoph Konrath/Benedikt Speer (2014), Die wissenschaftliche (Nicht-)Beschäftigung mit der Verwaltung und ihrem Verhältnis zur Politik in Österreich, in: Österreichische Zeitschrift für Politikwissenschaft, Vol. 43(4), 349-365

Blum, Sonja/Klaus Schubert (eds.) (2013), Policy analysis in Germany, Bristol: Policy Press.

Eder, Nikolaus/Marcelo Jenny/Wolfgang C. Müller (2015), Winning Over Voters or Fighting Party Comrades? Personalized Constituency Campaigning in Austria, in: Electoral Studies 39, 316-328.

Ehs, Tamara/Thomas König (2012), Wissenschaft von der Politik vor der Politikwissenschaft? In: Österreichische Zeitschrift für Politikwissenschaft, Vol. 4I(2), 2 II-227.

Fortin-Rittberger, Jessica/Berthold Rittberger (2013), Do Electoral Rules Matter? Explaining National Differences in Women's Representation in the European Parliament, in: European Union Politics, Vol. I5(4), 496-520.

Hanisch, Ernst (1994), Der lange Schatten des Staates. Österreichische Gesellschaftsgeschichte im 20. Jahrhundert, Wien: Ueberreuter

Konrath, Christoph (2014), Parliaments and comparative law. A practitioner's view, in: Lachmayer, Kon$\mathrm{rad} / J u ̈ r g e n$ Busch/Jennifer Kelleher/Geanina Turcanu (eds.), International Constitutional Law in Legal Education: Proceedings of the Erasmus Intensive Programme NICLAS 2007-2012, Schriften zum Internationalen und Vergleichenden Öffentlichen Recht, Band 19, Wien-Baden-Baden: Facultas/Nomos, $75-86$

Leston-Bandeira, Cristina (2012), Studying the Relationship between Parliaments and Citizens, in: Journal of Legislative Studies, I8, 265-274.

Parlamentskorrespondenz (2017), NR-Präsidentin Doris Bures präsentiert „Foresight und Technikfolgenabschätzung im Österreichischen Parlament", No. 780/2017-06-22.

Praprotnik, Katrin/Marcelo Jenny/Wolfgang C. Müller (2015), Sozialpartnerschaftliche Politikberatung: Das Auslaufen eines Modells, in: Zeitschrift für Politikberatung, 7, 79-90.

Rosenberger, Sieglinde/Jeremias Stadlmaier (2015), Direkte Demokratie - Regierungstechnik oder Instrument der BürgerInnen?, in: Öhlinger, Theo/Klaus, Poier (eds.), Direkte Demokratie und Parlamentarismus, Wien-Graz-Köln: Böhlau, 227-25I. 
Somek, Alexander (2007), Wissenschaft vom Verfassungsrecht: Österreich, in: Bogdandy, Armin von/ Pedro Cruz Villalón/Peter M. Huber (eds.), Handbuch Ius Publicum Europaeum, Band II: Offene Staatlichkeit - Wissenschaft vom Verfassungsrecht, Heidelberg: C. F: Müller, 637-662.

Steger, Gerhard (2010), Austria's Budget Reform: How to Create Consensus for a Decisive Change of Fiscal Rules, OECD Journal on Budgeting IO, I-I4.

Wiederin, Ewald (2007), Denken vom Recht her: Über den modus austriacus in der Staatsrechtslehre, in: Schulze-Fielitz, Helmut (ed.), Staatsrechtslehre als Wissenschaft, Die Verwaltung Beiheft 7, 293-317.

Zaal, Karin (20I4), Policy Analysis in the Dutch Parliament, in: van Nispen, Frans/Peter Scholten (eds.), Policy Analysis in the Netherlands, Bristol: Policy Press, I7I-I85.

\section{Author}

Christoph Konrath, Dr. iur., MSc (LSE) is head of the Department of Academic Research and Support in Parliamentary Matters in the Austrian Parliamentary Administration. He coordinates the area of interest Parliamentary Practice and Procedure of the European Centre for Parliamentary Research and Documentation. He is member of the board of the Austrian Political Science Association and of the editorial board of this journal. 
